\title{
REDUCTION OF MICROBIAL CONTAMINATION OF WHOLE BROILER CHICKEN CARCASSES DURING PROCESSING
}

\author{
F.A. Khalafalla ${ }^{1}$, N.S. Abdel-Atty ${ }^{1}$, Soad, A. Nasef ${ }^{2}$ and Adel, S. Hanafy ${ }^{2 *}$ \\ ${ }^{1}$ Faculty of Veterinary Medicine, Beni Suef University, Egypt. \\ ${ }^{2}$ Animal Health Research Institute, Dokki, Giza, Egypt. \\ *Corresponding author: Adel, S. Hanafy; E-mail: vet adel2010@yahoo.com
}

\begin{abstract}
Contamination of broiler carcasses during processing with several microorganisms as salmonella, campylobacter, E. coli and staphylococcus aureus is frequently occurring. Scalding, defeathering, chilling are critical points at which cross contamination may occur during processing. Recently several interventions for carcass decontamination have been employed in order to reduce the levels of microbial hazards on poultry carcasses during processing; among which chlorine and organic acids are the most common. This study was carried out in a traditional poultry abattoir in Fayoum Governorate in order to improve the microbial quality of broiler carcasses. During 10 replicate a total of 160 carcasses were collected at 4 sampling points in the processing line (scalding, defeathering, final wash and chilling). Bacterial counts recovered from broiler carcasses rinse were lowered by $1.3,1.3,0.3$ and $0.5 \log _{10} \mathrm{cfu} \backslash \mathrm{ml}$ after treatment of scalding water with $100 \mathrm{ppm}$ Calcium hypochlorite in scalding. Adding peracetic acid (PAA) $50 \mathrm{ppm}+0.5 \%$ acetic acid to the defeathering machine spraying system during defeathering lowered the count of coliforms and faecal coliforms significantly ( $\mathrm{P}$ $\leq 0.05$ ) by 1.5 and $1.6 \log _{10} \mathrm{cfu} \backslash \mathrm{ml}$ of carcass rinse, while it wasn't significant for E. coli and staphylococcus counts $\left(1.2\right.$ and $0.95 \log _{10}$ $\mathrm{cfu} \backslash \mathrm{ml}$ ), respectively. Furthermore, significant differences in the reduction of all bacterial counts were observed in the washing stage $(\mathrm{P} \leq 0.05)$ after treatment of broiler carcasses with a mixture of lactic acid $1 \%+$ acetic acid $1 \%$ in the final washing step. At chilling stage $\mathrm{Na}$ hypochlorite $50 \mathrm{ppm}$ reduced the bacterial counts by 2, 2.2, 1.3 and $0.8 \log _{10} \mathrm{cfu} \backslash \mathrm{ml}$ of carcass rinse for coliforms, faecal coliforms, Escherichia coli and staphylococcus aureus, respectively. E. coli, salmonellae, staphylococcus aureus and campylobacter spp. were reduced by different percentages. The used interventions effectively or significantly reduced microbial populations on broiler chicken carcasses during processing.
\end{abstract}

Keywords: Acetic acid, chlorine, decontamination, poultry processing, Peracetic acid.

\section{INTRODUCTION}

Poultry meat is more popular in consumer market, inspite; they are frequently contaminated with wide variety of biological hazards of public health significance during processing such as Salmonella, Campylobacter, Staphylococcus aureus, Escherichia coli and Listeria., rendering it responsible for a significant number of human food poisoning cases which remains an important public health issue (Dincer and Baysal, 2004 and Scallan et al., 2011). A
Original Article:

DOI:https://dx.doi.org/10.21608/javs.2019.62670

Received 18 June, 2018.

Accepted 22 February, 2019.

Published in April, 2019.

This is an open access article under the term of the Creative Commons Attribution 4.0 (CC-BY) International License . To view a copy of this license, visit http://creativecommons.org/licenses/by/4.0/

J. Appl. Vet. Sci., 4(1): 5-12.

live healthy bird carries high numbers of different microorganisms on its feathers, skin, feet and in the intestine. The heavy bacterial loads coming the processing plant with live birds can be disseminated throughout the plant during processing (Berrang et al., 2000 and Göksoy et al., 2004).

Broiler slaughter's is a multi-stage operation consists of several processes as scalding, defeathering, evisceration, washing, chilling and packaging at any 
point of which cross contamination can occur (Rosenquist et al., 2006 and Allen et al., 2007). Although processing generally reduces overall microbial contamination of broiler carcasses (Göksoy et al., 2004), cross-contamination between carcasses can occurs from different sources such as scalding, chilling, processing water, feather plucking, evisceration and washing, equipment and operators' hands. These operations have potential to cause a significant increase in the prevalence of bacterial pathogens in broiler carcasses (Berrang et al., 2001 and Nidaullah et al., 2017).

Nowadays microbial safety and quality of commercially produced broiler carcasses are important goal and a major areas of concern. Reduction of broiler carcasses contamination and improving it's shelf-life are important goals and critical objectives in relation to poultry meat production (Okolocha and Ellerbroek, 2005). Multiple intervention strategies are used in theprocessing plant to reduce and eliminate bacterial contamination on broiler carcasses during processing as single intervention not enough. Addition of decontaminant agent is an important approach to control biological hazards during poultry processing. A variety of antimicrobial treatments for control of microbial contamination and improving the safety of broiler carcasses during processing have been investigated (Dickens and Whittemore, 1997). The commonly used antimicrobial agents are chlorine, and organic acids.

Chlorine is generally recognized as safe (GRAS) status and the most widely antimicrobial agent used as sanitizer in commercial poultry-processing facilities. It is inexpensive and relatively effective against microorganisms found in poultry-processing environments and has the ability to kill a wide range of microorganisms on carcasses, in processing water, and on processing equipment (Tsai et al., 1995). Furthermore it can be used in washing, immersion chillers, or equipment sprays to reduce microbial contamination and cross-contamination (Bailey et al., 1986; Northcutt et al., 2003 and Bashor et al., 2004).

Organic acids such as acetic and lactic acid, recognized as safe (GRAS) interventions and are used extensively by the meat and poultry industries to reduce bacterial contamination on carcass surfaces and increase the shelf-life (Dickson and Anderson, 1992).

Several studies demonstrated the effectiveness of lactic acid as an antimicrobial intervention in poultry processing intervention (Yang et al., 1998). Acetic acid has been used by various researchers in the scald water (Izat et al., 1989), picking sprays (Dickens and whittimore, 1997), prechill (Dickens and
Whittomore, 1994) and chill tanks (Dickens and Whittemore, 1995) to reduce microbial counts of broiler carcasses.Peracetic acid (PAA) is one of the approved antimicrobials which can be used in the processing plants in both chiller applications and postchill immersion tanks during poultry processing. Previous studies revealed that PAA is the more effective antimicrobial as compared with chlorine (Bauermeister et al., 2008 and Nagel et al., 2013).

Reducing the microbial hazards on finished carcasses requires implementation of multiplesequential interventions; previous studies have shown that even if an individual treatment does not have a significant effect, a series of treatments or overall processing may (Stopforth et al., 2007 and Berrang and Bailey, 2009). Therefore the current research was conducted to study the efficacy of some decontaminant chemical agents applied to broiler carcasses in multiple interventions during some processing points to minimize the risk of cross contamination in an attempt to improve the bacteriological quality of broiler carcasses.

\section{MATERIALS AND METHODS}

The current investigation was carried out in a traditional poultry abattoir located in Fayoum Governorate; the abattoir was operating 1 kill line at a speed of 50 bird $\backslash$ hour. Live birds are delivered to the slaughterhouse in transporting crates. Crates are unloaded and birds are manually hanged on the shackle line.

After slaughtering which was manually done without stunning; birds allowed to bleed completely 1$2 \mathrm{~min}$, carcasses proceeded to scalding through immersion in large tank contain hot water at $53-55^{\circ} \mathrm{C}$ for $2 \mathrm{~min}$, then the hanged birds in the shackle line pass through series of 4 automated feather-picking machines with rubber fingers (plucker). This step is followed by manually removal of viscera after opening of the body cavity. After giblet harvesting; head, crop, lungs and feet were manually removed then birds pass through washing tank and finally immersion chilling in cold water.

\section{1- Experiment design}

A total of 10 replicate were conducted; on each replicate 16 broiler carcasses were collected from 4 sampling sites resulting in a total of 160 carcasses were examined. The sampling points were scalding, defeathering, washing and chilling. Four carcasses were collected in each sampling site represented by two control and two treated 


\section{F.A. Khalafalla, et al.}

carcasses. Control carcasses were collected first before application of any antimicrobial treatment on each sampling site. After all control carcasses were collected, treatment interventions were started as in table (1).

Table 1: Treatment interventions to collected

\begin{tabular}{|c|c|}
\hline Site & Treatment \\
\hline Scalding & $\begin{array}{l}\text { - Calcium hypochlorite } 100 \mathrm{ppm} \\
\text { was added to scalding water. } \\
\text { - Broiler carcasses immersed in } \\
\text { the scalding water for } 2.5 \mathrm{~min} \\
\text { with scalding temperature } 53- \\
55^{\circ} \mathrm{C} \text {. }\end{array}$ \\
\hline Defeathering & $\begin{array}{l}\text { - Adding of peracetic acid } 50 \\
\text { ppm }+0.5 \% \text { acetic acid to the } \\
\text { defeathering machine spray } \\
\text { system. } \\
\text { - The spray was started } 15 \\
\text { second before carcasses entered } \\
\text { the picker to ensure that } \\
\text { treatment spray had completely } \\
\text { purged the system. } \\
\text { - The picking time was } 30 \\
\text { second. }\end{array}$ \\
\hline $\begin{array}{l}\text { Final } \\
\text { washing }\end{array}$ & $\begin{array}{l}\text { - Adding of organic acid mixture } \\
\text { (acetic acid } 1 \%+\text { lactic acid } 1 \\
\% \text { ) to the washing water. }\end{array}$ \\
\hline Chilling & $\begin{array}{l}\text { - Adding sodium hypochlorite } 50 \\
\text { ppm to the chiller tank water } \\
\text { for } 30 \text { min immersion at } \\
\text { temperature } 4-10{ }^{\circ} \mathrm{C} \text {. }\end{array}$ \\
\hline
\end{tabular}

carcasses

\section{2- Preparation of decontaminant}

A calculation was performed to determine the preferable final concentration of decontaminant in water. Calcium hypochlorite was used to prepare 100 ppm chlorine by adding $77 \mathrm{gm}$ powder of calcium hypochlorite $65 \%$ to 500 litre of water while $\mathrm{Na}$ hypochlorite $50 \mathrm{ppm}$ was prepared by adding $417 \mathrm{ml}$ of Na hypochlorite $12 \%$ to 500 litre of the chilling water. Acetic acid was used to prepare $1 \%$ by add $510 \mathrm{ml}$ of acetic acid $99.6 \%$ to 50 litre of water while lactic acid was prepared by add $575 \mathrm{ml}$ of lactic acid $88 \%$ to 50 liter water.

\section{3- Sampling procedure}

Broiler carcasses were removed from the processing line at random at each of 4 sites (after exiting scalding tank, after picking, after final wash and after exiting chilling tank), handled with new clean latex gloves and individually placed into a separate sterile plastic bags. Individual carcasses were subjected to whole-carcass rinses rinse (WCR) technique with $400 \mathrm{ml}$ of $0.1 \%$ sterile buffered peptone water (BPW) added to each bag and shaken by hand for $60 \mathrm{sec}$; after shaking, carcasses were removed aseptically and the rinse liquid was poured in sterile cups. Following the collection, all the containers of the recovered rinse liquid were placed in ice box and delivered to the reference laboratory for veterinary quality control on poultry production - Fayoum branch within 1 hour for examination.

\section{4- Microbiological analysis}

Carcasses rinsate for each individual carcass were serially diluted in sterile $0.1 \%$ buffered peptone water (BPW) solution. Serial dilutions of the collected rinsate were prepared up to $10^{-6}$ for examination of the following:

1-MPN of Coliforms, faecal coliforms and Escherichia coli: according to (FDA, 2002).

2-Staphylococcus aureus count: according to ISO 6888-1 (ISO, 1999).

3-Salmonella spp isolation: ISO 6579 (ISO, 2002).

4- Campylobacter spp isolation: ISO 10272-1 (ISO, 2006).

E. coli and salmonella isolates were subjected to serological identification in the central lab in Dokki. Group O polyvalent antisera were used for serotyping test by slide agglutination technique.

\section{Data analysis}

Mean bacterial counts were converted to $\log _{10}$ colony-forming units per $\mathrm{ml}(\mathrm{cfu} \backslash \mathrm{ml})$ of carcass rinse solution. Group means of bacterial counts were compared using unpaired $\mathrm{T}$ - test for each type of microorganism to determine significant differences in the number of bacteria recovered from treated and control carcasses. Statistical significance was set at Pvalue of $\leq 0.05$. The data were analyzed using GraphPad InStat version 3 for Windows 95. (GraphPad Software, 1998). 
Table 2: Mean log colony-forming units of bacterial counts detected per milliliter (cfu/ $\mathrm{ml}$ ) of broiler carcasses rinse collected before and after treatments during processing

\begin{tabular}{|c|c|c|c|c|c|c|c|c|c|c|c|c|}
\hline & \multicolumn{3}{|c|}{ Coliform count (MPN) } & \multicolumn{3}{|c|}{$\begin{array}{l}\text { Faecal coliform } \\
\text { (MPN) }\end{array}$} & \multicolumn{3}{|c|}{ E. coli count (MPN) } & \multicolumn{3}{|c|}{$\begin{array}{c}\text { Staphylococcus aureus } \\
\text { count }\end{array}$} \\
\hline & $\begin{array}{l}\hat{0} \\
\stackrel{0}{0}\end{array}$ & 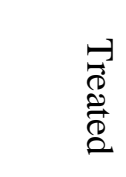 & 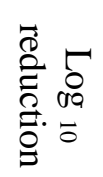 & $\begin{array}{l}\varrho \\
\stackrel{0}{0} \\
0\end{array}$ & 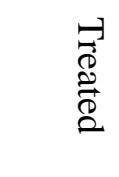 & 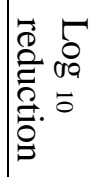 & $\begin{array}{l}\Omega \\
\varrho \\
0 \\
0\end{array}$ & 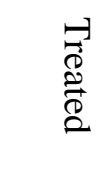 & 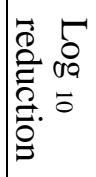 & $\begin{array}{l}\Omega \\
0 \\
0\end{array}$ & 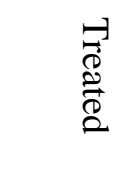 & $\begin{array}{l}\overrightarrow{0}: 5 \\
\stackrel{0}{0} \\
\stackrel{0}{0} \\
0 \\
0 \\
0\end{array}$ \\
\hline Scalding & $\begin{array}{l}5.2^{x} \\
\pm 5\end{array}$ & $\begin{array}{l}3.9^{x} \\
\pm 3.5\end{array}$ & 1.3 & $\begin{array}{l}5.1^{x} \\
\pm 5\end{array}$ & $\begin{array}{l}3.84^{\mathrm{x}} \\
\pm 3\end{array}$ & 1.3 & $\begin{array}{l}3.7^{x} \\
\pm 3\end{array}$ & $\begin{array}{l}3.4^{x} \\
\pm 3\end{array}$ & 0.3 & $\begin{array}{l}4.3^{\mathrm{x}} \\
\pm 3\end{array}$ & $\begin{array}{l}3.8^{y} \\
\pm 3\end{array}$ & 0.5 \\
\hline Defeathering & $\begin{array}{l}5.5^{x} \\
\pm 5\end{array}$ & $\begin{array}{l}4^{\mathrm{y}} \\
\pm 3.6\end{array}$ & 1.5 & $\begin{array}{l}5.4^{\mathrm{x}} \\
\pm 5\end{array}$ & $\begin{array}{l}3.8^{y} \\
\pm 3\end{array}$ & 1.6 & $\begin{array}{l}4.7^{x} \\
\pm 4\end{array}$ & $\begin{array}{l}3.5^{x} \\
\pm 3\end{array}$ & 1.2 & $\begin{array}{l}4.95^{\mathrm{x}} \\
\pm 4\end{array}$ & $\begin{array}{l}4^{\mathrm{x}} \\
\pm 3\end{array}$ & 0.95 \\
\hline Washing & $\begin{array}{l}5.7^{x} \\
\pm 5\end{array}$ & $\begin{array}{l}3.5^{y} \\
\pm 3\end{array}$ & 2.2 & $\begin{array}{l}5.5^{\mathrm{x}} \\
\pm 5\end{array}$ & $\begin{array}{l}3.4^{\mathrm{y}} \\
\pm 3\end{array}$ & 2.1 & $\begin{array}{l}5.3^{x} \\
\pm 5\end{array}$ & $\begin{array}{l}3^{y} \pm \\
2^{y}\end{array}$ & 2.3 & $\begin{array}{l}4^{\mathrm{x}} \\
\pm 3\end{array}$ & $<10^{\mathrm{y}}$ & ---- \\
\hline Chilling & $\begin{array}{l}5.6^{\mathrm{x}} \\
\pm 5\end{array}$ & $\begin{array}{l}3.5^{y} \\
\pm 3\end{array}$ & 2 & $\begin{array}{l}5.4^{x} \\
\pm 5\end{array}$ & $\begin{array}{l}3.2^{\mathrm{y}} \\
\pm 2.9\end{array}$ & 2.2 & $\begin{array}{l}4.2^{x} \\
\pm 3\end{array}$ & $\begin{array}{l}2.9^{x} \\
\pm 2\end{array}$ & 1.3 & $\begin{array}{l}3.8^{x} \\
\pm 3\end{array}$ & $\begin{array}{l}3^{x} \\
\pm 2\end{array}$ & 0.8 \\
\hline
\end{tabular}

${ }^{x, y}$ Mean bacterial count values within a row with no common superscripts are significantly different for each group at $(\mathrm{P} \leq 0.05)$. Counts are expressed as mean $\pm \mathrm{S} . \mathrm{E}\left(\log _{10} \backslash \mathrm{ml}\right)$. Mean from 10 replications with 4 carcasses per site per replication.

Table 3: Prevalence (\%) of isolated microorganisms in broiler carcass rinses collected before and after treatments during broiler processing

\begin{tabular}{|c|c|c|c|c|c|}
\hline \multirow{4}{*}{ site } & Treatment & E. coli & Salmonella spp & $\begin{array}{c}\text { Staphylococcus } \\
\text { aureus }\end{array}$ & $\begin{array}{c}\text { Campylobacter } \\
\text { spp }\end{array}$ \\
\hline \multirow{4}{*}{ Scalding } & Control & $16120(80 \%)$ & $8120(40 \%)$ & $18120(90 \%)$ & $18120(90 \%)$ \\
\cline { 2 - 6 } & treated & $14120(70 \%)$ & $4120(20 \%)$ & $8120(40 \%)$ & $12120(60 \%)$ \\
\cline { 2 - 6 } & Reduction \% & $12.5 \%$ & $50 \%$ & $55 \%$ & $33 \%$ \\
\hline \multirow{4}{*}{ Defeathering } & Control & $16120(80 \%)$ & $8120(40 \%)$ & $20120(100 \%)$ & $14120(70 \%)$ \\
\cline { 2 - 6 } & treated & $16120(80 \%)$ & $6120(30 \%)$ & $14120(70 \%)$ & $14120(70 \%)$ \\
\cline { 2 - 6 } & Reduction \% & Zero & $25 \%$ & $30 \%$ & Zero \\
\hline \multirow{3}{*}{ Washing } & Control & $18120(90 \%)$ & $10120(50 \%)$ & $12120(60 \%)$ & $16120(80 \%)$ \\
\cline { 2 - 6 } & treated & $10120(50 \%)$ & $2120(10 \%)$ & zero & $4120(20 \%)$ \\
\cline { 2 - 6 } & Reduction \% & $44 \%$ & $80 \%$ & $100 \%$ & $75 \%$ \\
\hline \multirow{3}{*}{ Chilling } & Control & $16120(80 \%)$ & $10120(50 \%)$ & $12120(60 \%)$ & $16120(80 \%)$ \\
\cline { 2 - 6 } & treated & $12120(60 \%)$ & $6120(30 \%)$ & $6120(30 \%)$ & $8120(40 \%)$ \\
\cline { 2 - 6 } & Reduction \% & $25 \%$ & $40 \%$ & $50 \%$ & $50 \%$ \\
\hline
\end{tabular}




\section{F.A. Khalafalla, et al.}

Table 4: Isolates serotypes of Salmonella and E. coli

\begin{tabular}{|c|c|c|}
\hline Stage & Salmonella & E. coli \\
\hline Scalding & $\begin{array}{c}\text { S.Virchow, S. Aba, } \\
\text { S. Kentucky }\end{array}$ & O1, O127, \\
& O26 \\
\hline Defeathering & S.Virchow, S. Aba & O119, O44 \\
\hline Washing & S. Aba, S. Infantis & O44, O26, \\
& & O78 \\
\hline Chilling & S. Aba, S.Virchow, & O26, O78 \\
& S. Kentucky & \\
\hline
\end{tabular}

\section{DISCUSSION}

Immersion scalding presents one of the earliest opportunities for carcass cross-contamination to occur earlier reports that emphasized that the efficacy of chlorine as an antimicrobial agent is affected by $\mathrm{pH}$, the presence of organic material, and contact time. In this context, Byrd and McKee (2005) found that the efficacy of chlorine for bacterial reduction decreases with increasing $\mathrm{pH}$ and organic load. Traditional scalding of poultry use only one single tank which serve as a mean of cross contamination, birds entering the slaughterhouse are often heavily contaminated with faecal material, when birds are immersed in the scalding tank, dirt, fecal material, and other surface contaminants are removed this results in contaminated scald water making the scald tank a source of crosscontamination for subsequent carcasses, this agreed with that reported by (Cason et al., 1997 and Göksoy et al., 2004).

Previous research treated the scalding water with chemicals such as acetic acid observed no significant difference on bacterial counts or salmonella incidence in broiler carcasses when scald water treated with acetic acid $0.5 \%$ (Lillard et al., 1987). Furthermore Izat et al., (1990) used lactic acid at concentrations of $1 \%$ in scalding and found no reduction in the incidence of salmonellae on carcasses subjected to lactic acid in the scald water. On contrast, Sakhare et al., (1999) found that counts of staphylococcus aureus, and coliforms were lower in birds scalded in acidified water, although, this reduction was not significant. Moreover, spray washing of carcasses with acetic or lactic acid after scalding reduced the counts of staphylococcus aureus and coliforms significantly.

Results from table (2) showed that peracetic acid $50 \mathrm{ppm}+$ acetic acid $0.5 \%$ spray during defeathering reduced coliforms (MPN), faecal coliforms (MPN), E. coli (MPN) and staphylococcus aureus count by 1.5, 1.6, 1.2 and $0.95 \log _{10} \mathrm{cfu} \backslash \mathrm{ml}$ of carcass rinse, respectively. Salmonella spp. and during the processing operation, the scald tank is considered to be the major site of cross contamination from one carcass to another through scald water.

Calcium hypochlorite $100 \mathrm{ppm}$ in scalding water reduced coliforms (MPN), faecal coliforms (MPN), E. coli (MPN), staphylococcus aureus count by $1.3,1.3,0.3$ and $0.5 \log _{10} \mathrm{cful} \mathrm{ml}$ of carcass rinse, respectively. This reduction was significant only for staphylococcus aureus count while, counts of coliforms (MPN), faecal coliforms (MPN), E. coli (MPN) didn't significantly altered (table 2). Moreover, E. coli, salmonella spp, staphylococcus aureus and campylobacter spp were reduced by $12.5 \%, 50 \%, 55 \%$ and $33 \%$, respectively (table 3 ). The isolated E. coli serotypes during this stage were $\mathrm{O} 1, \mathrm{O} 127, \mathrm{O} 26$ while salmonella serotypes were S.Virchow, S. Aba, S. Kentucky (table 4). This finding supports

staphylococcus aureus were reduced by $25 \%$ and $30 \%$, respectively while $\mathrm{E}$. coli and campylobacter spp. remain the same (table 3). The isolated E. coli serotypes during this stage were $\mathrm{O} 119$ and $\mathrm{O} 44$ while the isolated salmonella serotypes were S.Virchow, S. Aba (table 4).

Data from table (2) showed that spray of broiler carcasses during picking with mixture of peracetic acid $50 \mathrm{ppm}$ and acetic acid $0.5 \%$ reduced the count of coliforms and faecal coliforms significantly while it wasn't significant for $E$. coli and staphylococcus aureus counts $(p \leq 0.05)$. The defeathering machine is also reported as a major site of bacterial cross contamination of broiler carcasses during processing because of contact with contaminated rubber picking fingers (Geornaras et al., 1997). External pressure exerted on the lower abdomen by the picker's rubber fingers induce some pressure on the carcasses so that highly contaminated fecal material is forced out from the vent contaminating carcasses during picking (Berrang et al., 2001).

Previous investigations have shown that, in counts of campylobacter, salmonella and staphylococcus aureus increase following plucking (Abu-Rwaida et al., 1994; Geornaras, et al., 1997 and Berrang et al., 2001). Previously published reports investigated many antimicrobial interventions to lessen bacterial contamination on broiler carcasses during or after defeathering stage. A study conducted by Berrang et al., (2011) reported that spraying chlorine dioxide during defeathering lower numbers of campylobacter, E. coli and salmonella on broiler carcasses. Furthermore Sakhare et al., (1999) observed significant reduction in coliform and staphylococcus aureus counts on broiler carcasses after the acid treatment (dipping or spraying lactic or acetic acid after defeathering). On the other hand, Lillard et al., (1987) 
found that spray solution of $0.5 \%$ acetic acid in the plucking machine spray line did not improve the bacterial quality of picked carcasses.

Little or no attention has been given to the effects of PAA as antimicrobial in the spray water of defeathering equipment. PAA is commonly used as alternative to chlorine during chilling and post chilling (Bauermeister et al., 2008) in this respect, Nagel $\boldsymbol{e t}$ al., (2013) reported reductions in both salmonella and campylobacter over $2.0 \log _{10} \mathrm{cfu} / \mathrm{mL}$ when use PAA in post-chill immersion tank. Based on the result of intervention used in this study during defeathering stage it would be advisable to add $0.5 \%$ acetic acid + PAA $50 \mathrm{ppm}$ to the spray water of defeathering machine to improve microbiological quality of broiler carcasses.

It is common for plants to apply any form of washing after evisceration as broiler evisceration can result in gut rupture and leakage, potentially increasing bacterial numbers on carcasses. However, using water without antimicrobial agent in washing stage may not significantly reduce carcass coliform or E. coli counts (Northcutt et al., 2003).Data presented here showed that the bacteriological quality of broiler carcasses was improved and the microbial count was significantly decreased $(\mathrm{p} \leq 0.05)$ after addition of acid mixture (lactic acid $1 \%+$ acetic acid 1\%) during washing stage as compared with control carcasses washed with water alone, results from table (2) showed that all the bacterial count were reduced significantly at $\mathrm{p} \leq 0.05$. Coliforms (MPN), faecal coliforms (MPN), E. coli (MPN) were reduced by 2.2, 2.1, $2.3 \log 10 \mathrm{cfu} \backslash \mathrm{ml}$ respectively, in addition Staphylococcus aureus count was lowered to non-detectable level. E. coli, salmonella spp, Staphylococcus aureus and campylobacter spp were reduced by $44 \%, 80 \%, 100 \%$ and $75 \%$ respectively (table 3 ). The isolated E. coli serotypes during this stage were $\mathrm{O} 44, \mathrm{O} 26$, O78 while the isolated salmonella serotypes were S. Aba, S. Infantis (table 4).

Northcutt et al., (2005) observed that washing with $50 \mathrm{ppm}$ of chlorinated water did not significantly reduce the counts of E. coli, Salmonella or Campylobacter recovered from the carcasses rinse. Moreover, Killinger et al., (2010) reported that chlorine produce much smaller reduction than that observed by $2 \%$ lactic acid immersion of broiler carcass after washing which produce significant microbial reductions in coliform and salmonella levels.

Several studies investigating the antibacterial efficacy of lactic acid spraying on prechill carcasses and found salmonella reductions by $0.6-1.8 \log$ CFU/carcass (Yang et al., 1998). Moreover, a study conducted by Xiong et al., (1998) illustrated that $1 \%$ and $2 \%$ lactic acid solution sprayed on chicken skin samples brought about a $2.2 \log _{10}$ reduction in Salmonella on chicken carcasses. Similarly, Rasschaert et al., (2013) reported that after submerging broiler carcasses in a $1.5 \%$ lactic acid solution, significant reduction of campylobacter 1.62 and $1.24 \mathrm{log}$ cfu/carcass were observed compared with the control carcasses submerged in water.The results obtained during this study indicated that mixture of lactic acid $1 \%+$ acetic acid $1 \%$ combination could significantly reduce the microbial load on carcasses, minimize the cross contamination and was found to be the more effective as a decontamination intervention through the final washing stage during broiler processing.

The carcass chilling process is considered as a critical step in poultry processing. Water immersion chilling is the most widely used method to lower broiler carcass temperature during processing. Traditionally, chlorine is the antimicrobial commonly applied in commercial poultry processing plants and is allowed up to $50 \mathrm{ppm}$ for the chlorination of chilled water to prevent cross-contamination and reducing bacterial contamination (Tsai et al., 1995). Results from table (2) showed that $\mathrm{Na}$ hypochlorite $50 \mathrm{ppm}$ during chilling stage reduce coliforms (MPN), faecal coliforms (MPN), E. coli (MPN) and Staphylococcus aureus count by $2,2.2,1.3$ and $0.8 \log _{10} \mathrm{cfu} \backslash \mathrm{ml}$ of carcass rinse.

The reduction in counts of coliforms and faecal coliforms was significant $(p \leq 0.05)$ while it appear to be small or non-significant reduction on E. coli and Staphylococcus aureus counts. E. coli, salmonella spp, staphylococcus aureus and campylobacter spp. were reduced by $25 \%, 40 \%, 50 \%$ and $50 \%$, respectively. In this context, Stopforth et al., (2007) noticed that the bacterial count, coliforms and E. coli were significantly lowered after using chlorine $50 \mathrm{ppm}$ in chilling. Furthermore, Yang et al., (2001) reported reduction of salmonella and campylobacter to non-detectable levels with 30 and $50 \mathrm{ppm}$ of chlorine in chill water. Also, Mead et al., (1995) examined the effect of process water chlorination at several stages in poultry slaughter including the chiller water and found that the numbers of campylobacter were significantly reduced.

In a study conducted by Lillard (1980) comparing chlorine treated chill water with non chlorinated chill water, the researcher found that the incidence of Salmonella and faecal coliforms was significantly lower in chlorine-treated chill water versus non-chlorinated chill water. This is in consistent with a previous study by Izat $\boldsymbol{e t}$ al., (1989) in which chlorine $100 \mathrm{ppm}$ in chill water reduced salmonella significantly. However, Fabrizio et al., (2002) used a lower concentration of chlorine (20 ppm) was used in immersion chilling treatment and yield non-significant reduction on salmonella, E. coli, and coliforms. 


\section{CONCLUSION}

From data in the present study it can be concluded that decontamination of broiler carcasses at each stage of processing either by addition of chlorine to scald and chill water, spraying of carcasses during defeathering or add organic acids to washing water help in minimizing the cross contamination and improve the microbiological quality of processed carcasses. Therefore multiple sequential antimicrobial interventions is of great importance in reducing the bacterial population in broiler carcasses during processing.

\section{ACKNOWLEDGMENT}

We are extremely grateful to the members of Reference lab for veterinary control on poultry production Fayoum branch for their help in the accomplishment of this work.

\section{Declaration of Competing interest}

On behalf of all authors, I hereby declare that no conflict of interest may interfere with the publication of the manuscript

\section{REFERENCES}

ABU-RUWAIDA, A.S., SAWAYA, W.N., DASHTI, B.H., MURAD, M. AND AL-OTHMAN, H.A. 1994. Microbiological quality of broilers during processing in a modern commercial slaughterhouse in Kuwait. J. food prot., 57: 887-892.

ALLEN, V.M., BULL, S.A., CORRY, J.E., DOMINGUE, G., JØRGENSEN, F., FROST, J.A., WHYTE, R., GONZALEZ, A., ELVISS, N. AND HUMPHREY, T.J. 2007. Campylobacter spp. contamination of chicken carcasses during processing in relation to flock colonisation. Int. J. Food Microbiol, 113: 54-56.

BAILEY, J. S., THOMSON, J. E., COX, N. A. AND SHACKELFORD, A. D. (1986): Chlorine spray washing to reduce bacterial contamination of poultry processing equipment. Poult. Sci., 65: 1120-1123.

BASHOR, M. P., CURTIS, P. A., KEENER., K. M., SHELDON, B. W., KATHARIOU, S. AND OSBORNE, J. A. 2004. Effects of Carcass Washers on Campylobacter Contamination in Large Broiler Processing Plants. Poult. Sci., 83: 1232- 1239.

BAUERMEISTER, L.J., BOWERS, J.W.J., TOWNSEND, J.C. AND MCKEE, S.R. 2008. Validating the efficacy of peracetic acid mixture as an antimicrobial in poultry chillers. J. Food Prot., 7: 119122.

BERRANG, M. E. AND BAILEY, J. S. 2009. On-line brush and spray washers to lower numbers of Campylobacter and Escherichia coli and presence of Salmonella on broiler carcasses during processing. J. Appl. Poult. Res., 18: 74-78.

BERRANG, M. E., BUHR, R. J., CASON, J. A. AND DICKENS, J. A. 2001. Broiler Carcass Contamination with Campylobacter from Feces during Defeathering. J. Food Prot., 64: 2063-2066.

BERRANG, M. E., MEINERSMANN, R. J., COX, N. A. AND FEDORKA-CRAY, P. J.2011. Application of chlorine dioxide to lessen bacterial contamination during broiler defeathering. J. Appl. Poult. Res., 20 : 33-39.

BERRANG, M.E., BUHR, R.J AND CASON, J.A. 2000. Campylobacter recovery from external and internal organs of commercial broiler carcass prior to scalding. Poult. Sci., 79: 286-290.

BYRD, J.A. AND MCKEE, S.R. 2005. Improving slaughter and processing technologies. In: Mead, G.C. (Ed.), Food Safety Control in the Poultry Industry. CRC Press LLC, Boca Raton, FL, pp. 310-327.

CASON, J. A., BAILEY, J. S., STERN, N. J., WHITTEMORE, A. D. AND COX, N. A. 1997. Relationship between aerobic bacteria, salmonellae, and Campylobacter on broiler carcasses. Poult. Sci. 76: 1037-1041.

DICKENS, J. A. AND WHITTEMORE, A. D. 1997. Effects of Acetic Acid and Hydrogen Peroxide Application During Defeathering on the Microbiological Quality of Broiler Carcasses Prior to Evisceration. Poult. Sci., 76: 657-660.

DICKENS, J. A. AND WHITTEMORE, A. D. 1994. The effect of acetic acid and air injection on appearance, moisture pick-up, microbiological quality, and Salmonella incidence on processed poultry carcasses. Poult. Sci., 73: 582-586.

DICKENS, J.A. AND WHITTEMORE, A.D. 1995. The effects of extended chilling times with acetic acid on the temperature and microbiological quality of processed poultry carcasses. Poult. Sci., 74: 10441048.

DICKSON, J. S. AND ANDERSON, M. E. 1992. Microbiological decontamination of food animal carcasses by washing and sanitizing systems: a review. J. Food Prot., 55: 133-140.

DINCER, A. H., BAYSAL, T. 2004. Decontamination techniques of pathogen bacteria in meat and poultry. Crit. Rev. Microbiol., 30: 197- 204.

FABRIZIO, K. A., SHARMA, R. R., DEMIRCI, A. AND CUTTER, C. N. 2002. Comparison of electrolyzed oxidizing water with various antimicrobial interventions to reduce Salmonella species on poultry. Poult. Sci., 81: 1598-1605.

FDA (2002): BAM (Bacteriological Analytical Manual) Chapter4: Enumeration of Escherichia coli and the Coliform Bacteria.

GEORNARAS, I., DE JESUS, A. E., VAN ZYL, E. AND VAN HOLY, A.1997. Bacterial populations of different sample types from carcasses in the dirty area of a South African poultry abattoir. J. Food Prot., 60: 551-554.

GÖKSOY, E. O., KIRKAN, S. AND KOK, F. 2004. Microbiological quality of broiler carcasses during processing in two slaughterhouses in Turkey. Poult. Sci., 83: 1427-1432.

GRAPHPAD SOFTWARE, INSTAT GUIDE TO CHOOSING AND INTERPRETING STATISTICAL TESTS 1998. GraphPad Software, San Diego, CA, USA, http://www.graphpad.com. 
INTERNATIONAL ORGANIZATION FOR STANDARDIZATION, ISO $10272 \quad 2006$. Microbiology of Food and Animal Feeding Stuffs Horizontal method for enumeration of campylobacter spp. part 1 detection method. Geneva, Switzerland.

INTERNATIONAL ORGANIZATION FOR STANDARDIZATION, ISO $6579 \quad \mathbf{. 2 0 0 2}$. Microbiology of Food and Animal Feeding Stuffs Horizontal Method for the detection of Salmonella spp. ISO, Geneva, Switzerland.

INTERNATIONAL ORGANIZATION FOR STANDARDIZATION, ISO $6888 \quad .1999$. Microbiology of Food and Animal Feeding Stuffs Horizontal method for the enumeration of coagulasepositive staphylococci (Staphylococcus aureus and other species) - part 1: technique using Baird-Parker agar medium. Geneva, Switzerland.

Izat, A. L., Colberg, M., Adams, M. H., Reiber, M. A. and. WALDROUP P. W. 1989. Production and processing studies to reduce the incidence of salmonellae on commercial broilers. J. Food Prot. 52:670-673.

Izat, A. L., Coldberg, M., Thomas, R. A., Adams, M. H. and DRIGGERS, C. D. 1990. Effects of lactic acid in processing waters on the incidence of Salmonella on broilers. J. Food Qual., 13:295-306.

KILLINGER, K.M., KANNAN, A., BARY, A.I. AND COGGER, C.G. 2010. Validation of a 2 Percent Lactic Acid Antimicrobial Rinse for Mobile Poultry Slaughter Operations. J. Food Prot., 73: 2079-2083.

LILLARD, H. S. 1980. Effect on broiler carcasses and water of treating chiller water with chlorine or chlorine dioxide. Poult. Sci., 59: 1761-1766.

LILLARD, H. S., BLANKENSHIP, L. C., DICKSON, J. A., CRAREN, S. E. AND SHACKELFORD, A. D. 1987. Effect of acetic acid on the microbiological quality of scalded picked and unpicked broiler carcasses. J. Food Prot., 50: 112-114.

MEAD G. C., HUDSON, W.R. AND HINTON, M.H. 1995. Effect of changes in processing to improve hygiene control on contamination of poultry carcasses with campylobacter. Epidemiol. Infect., 115: 495-500.

NAGEL, G. M., BAUERMEISTER, L. J., BRATCHER, C. L., SINGH, M. AND MCKEE., S. R. 2013. Salmonella and Campylobacter reduction and quality characteristics of poultry carcasses treated with various antimicrobials in a post-chill immersion tank. Int. J. Food Microbiol. 165: 281-286.

NIDAULLAH, H., ABIRAMI, N., SHAMILASYUHADA, A. K., CHUAH, L. O., NURUL, H., TAN, T. P., ABIDIN, F.W. Z. AND RUSUL, G. 2017. Prevalence of Salmonella in poultry processing environments in wet markets in Penang and Perlis, Malaysia. Vet. World., 10: 286 -292.

NORTHCUTT, J. K., BERRANG, M. E., SMITH, D. P. AND JONES, D. R. 2003.: Effect of commercial bird washers on broiler carcass microbiological characteristics. J. Appl. Poult. Res., 12: 435- 438.

NORTHCUTT, J. K., SMITH, D. P., MUSGROVE, M. T., INGRAM, K. D. AND HINTON, JR. A. 2005. Microbiological impact of spray washing broiler carcasses using different chlorine concentrations and water temperatures. Poult. Sci., 84: 16481652.

OKOLOCHA, E. C. AND ELLERBROEK, L. 2005. The influence of acid and alkaline treatments on pathogens and the shelf life of poultry meat. Food Control., 16: 217-225.

RASSCHAERT, G., PIESSENS, V., SCHELDEMAN, P., LELEU, S., STALS, A., HERMAN, L., HEYNDRICKX, M. AND MESSENS, W. 2013. Efficacy of electrolyzed oxidizing water and lactic acid on the reduction of Campylobacter on naturally contaminated broiler carcasses during processing. Poult Sci., 92: 1077-1084.

ROSENQUIST, H., SOMMER, H.M., NIELSEN, N.L. AND CHRISTENSEN, B.B. 2006. The effect of slaughter operations on the contamination of chicken carcasses with thermotolerant Campylobacter. Int. J. Food. Microbiol., 108: 226232.

SAKHARE, P. Z., SACHINDRA, N. M., YASHODA, K. P. AND RAO, D. N. 1999. Efficacy of intermittent decontamination treatments during processing in reducing the microbial load on broiler chicken carcass. Food Control., 10: 189-194.

SCALLAN, E., HOEKSTRA, R. M., ANGULO, F. J., TAUXE, R. V., WIDDOWSON, M. A. AND ROY, S. L. 2011. Foodborne illness acquired in the United States-major pathogens. Emerg. Infect. Dis., 17: 7-15.

STOPFORTH, J. D., O'CONNOR, R., LOPES, M., KOTTAPALLI, B., HILL, W. E. AND SAMADPOUR, M. 2007. Validation of individual and multiple-sequential interventions for reduction of microbial populations during processing of poultry carcasses and parts. J. Food Prot. 70: 13931401.

TSAI, L. S., HIGBY, R. AND SCHADE, J. 1995. Disinfection of poultry chiller water with chlorine dioxide: consumption and byproduct formation. J. Agric. Food Chem. 43: 2768-2773.

XIONG, H., LI, Y., SLAVIK, M. F. AND WALKER, J. T. 1998. Spraying chicken skin with selected chemicals to reduce attached Salmonella typhimurium. J. Food Prot., 61: 272-275.

YANG, H., LI, Y. AND JOHNSON, M. G. 2001. Survival and death of Salmonella typhimurium and Campylobacter jejuni in processing water and on chicken skin during poultry scalding and chilling. J. Food Prot., 64: 770-776.

YANG, Z., LI, Y. AND SLAVIK, M. 1998. Use of antimicrobial spray applied with an inside-outside bird washer to reduce bacterial contamination on prechilled chicken carcasses. J. Food Prot. 61, 829832 .

How to cite this article:

F.A. Khalafalla; N.S. Abdel-Atty; Soad A. Nasef and Adel S. Hanafy, 2019. Reduction of Microbial Contamination of Whole Broiler Chicken Carcasses During Processing. Journal of Applied Veterinary Sciences, 4(1): 5- 12. DOI : https://dx.doi.org/10.21608/javs.2019.62670 